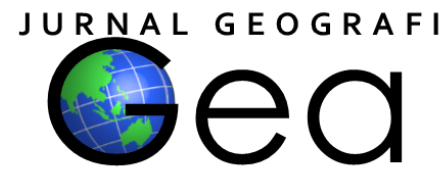

\title{
DEVELOPMENT OF WASTE BANK ACTIVITIES TO SUPPORT THE CITARUM HARUM
}

\author{
Dede Rohmat ${ }^{1}$, Diva Nugraha ${ }^{2}$, Iwan Setiawan ${ }^{3}$ \\ 1,2,3 Department of Geography Education, Universitas Pendidikan Indonesia \\ 1dederohmat64@gmail.com, 2divanugraha17@gmail.com,3iwansetiawan@upi.edu
}

\begin{abstract}
The Waste Bank is an effort to control pollution in the Citarum River. The development of the program needs to be monitored to see its sustainability. This study aims to examine the development of the Waste Bank around the Citarum River, in this case in the Bojongsoang and Dayeuhkolot Districts. The research method used a survey of the waste banks in the two districts. The research subject is the management of each Waste Bank. The results show that until 2018 there is a tendency for the number of Waste Banks to increase. However, the number of Waste Banks has decreased since 2019, even the number of Waste Banks in only one location is active in 2020.
\end{abstract}

Keywords: Development, Waste Bank, Citarum Harum

\section{INTRODUCTION}

The Citarum watershed is the largest in West Java with an area of 6,614 $\mathrm{km}^{2}$ and a river length of $269 \mathrm{~km}$ (Cahyaningsih \& Harsoyo, 2010). In Indonesia, the Citarum watershed is recorded as a watershed with a supercritical condition (Sipayung, et al, 2014 ). Criticality can be seen from the quality indicator of the river water is very bad. So that one of these water sources can no longer be used to meet daily needs because the river is polluted (Cahyaningsih \& Harsoyo, 2010). Based on the results of Rohmat's (2018) research, the content of several identified pollutants has exceeded the applicable quality standards. The laboratory test results for the entire sample plot of the study show that the Citarum River has a very high level of pollution.

According to Rohmat (2018), the main sources of the pollution load are industrial activities and domestic waste, which are directly channeled into rivers, such as garbage and chemical waste (Pamungkas, et al. 2019). The same thing was conveyed by Ermawati, et al. (2017) who stated that the source of river pollution is mostly generated from industrial and domestic waste, both liquid and solid. Contribution of pollutant sources from households and industry, especially in densely populated areas and industrial areas in several segments of the Citarum River. The lack of public awareness in managing waste (Hartono, et al., 2020) and community ignorance of the cleanliness of the Citarum River cause the condition and cleanliness of the surrounding environment to pay more attention (Rosita, 2017). According to Pamungkas, et al. (2019) other factors that cause pollution in the Citarum watershed are weak enforcement of regulations for pollution actors and limited infrastructure in data provision and monitoring systems. Marganingrum (2013) suggests that sanitation infrastructure and domestic waste treatment need to be improved and/or developed. 
Many waste management models and methods have been developed by several experts and institutions, such as the provision of facilities and infrastructure, implementing a retribution system to socializing environmental control and management (Widiyanto, et al. 2017). Various community -based small - scale waste management efforts by reusing waste that has the potential to be recycled (Dwiyanto, 2011) and large-scale waste management by designating waste disposal sites, both temporary and final disposal, have been carried out. One of the management models by modeling the system Waste Bank. Waste Bank is a place for selecting and collecting waste that can be recycled or reused which has economic value (Regulation of the Minister of Environment of the Republic of Indonesia Number 13 of 2012 ). According to Friedberg and Hilderbrand (2017), Waste Bank works like a bank where people in a community, sub-district, and district can deposit their waste or make money from the value of the waste. Suwerda (2012) emphasizes that the objectives of the procurement of this Waste Bank include three main aspects, namely the health aspect, the education aspect, and the socio-economic aspect (Hartono, et al. 2020).

The Waste Bank Program could also be seen as a movement for the handling of waste more realistic by taking into account the economic value that is obtained by the owner of the garbage. Although the economic motivations are dominant, they are expected to develop an understanding and awareness and environmental concern because the concept of management garbage should be based on developing sustainable and environmentally friendly (Surjandari, et al., 2009). Iswanto said that the existence of a Waste Bank is important because it is better for the garbage that is buried in the house to be saved than wasted or burned
(Saputro, 2015). According to Pariatamby and Tanaka (2014), the Waste Bank is a campaign to deal with the problem of waste by buying it back and saving the money from the previous waste in a banking system.

The Waste Bank Program is based on the benefits of waste for humans and has economic value. This program is also a waste management campaign by buying back waste in the form of deposits such as in the bank system. Conversion of waste with a value for money is expected to be able to create an educated and appreciative society for waste so that it is willing to sort waste (Dirjen Cipta Karya, 2011). Waste that has commercial value and generates profit can be a source of income, so this system can attract the private sector to invest funds in the procurement of waste processing technology (Surjandari, 2009).

The Ministry of Environment and Forestry of the Republic of Indonesia stated that there were 5,244 Waste Banks spread across 34 provinces or 219 districts/cities in Indonesia in 2017. The contribution of Waste Banks to waste reduction in Indonesia in 2015 was relatively small, namely, only 0.01 percent, in 2016 it rose to 0.14 percent, and there was a significant increase in 2017, namely 1.7 percent. In the economic field, Waste Bank has a potential populist is large enough with real output in the form of the opportunity of working in garbage management and investment savings (Saputro, 2015). Also, Waste Banks in Indonesia have succeeded in employing 163,128 people, of which 49 percent are women and most of them are housewives (Central Statistics Agency, 2018).

Collective management of this waste can encourage the community to play an active role in it (Yayasan Unilever Indonesia, 2013). The optimal level of the Waste Bank program can be achieved if 
there is an active role from various parties including the community, government, and companies that are interrelated (Widiyanto, 2017). The development of the Waste Bank certainly needs to be continuously monitored and evaluated because this program is ideal and will have a good impact and support the Citarum Harum program if it continues to develop. Therefore, this study aims to examine the development of the Waste Bank and the factors that influence its development in the Bojongsoang and Dayeuhkolot Districts, which are located by the Citarum River.

\section{RESEARCH METHOD}

This research was conducted in the Bandung Regency area, precisely in the Zone 2C / Segment 4 section of the Citarum watershed. This zone includes two sub-districts, namely Bojongsoang District and Dayeuhkolot District. The research subjects consisted of administrators or former administrators. The samples were interviewed as many as 14 officials and former board, 4 Rukun
Tetangga and Rukun Warga, 2 employee districts. The data were obtained by using the instruments of interview guidelines, documentation study, and observation. Documentation studies are carried out to trace secondary data on the number and distribution of Waste Banks and the development of Waste Banks. Direct observations were made by conducting field surveys to the research location to determine field conditions. The procedures for this research are as follows.

1. Study or review of previous theories and research

2. Preparation of research instruments

3. Waste Bank data collection from related agencies

4. Making a digital map of the study area, namely Dayeuhkolot and Bojongsoang Districts

5. Plotting the location of the Waste Bank on the map

6. Analysis of the development of the Waste Bank.

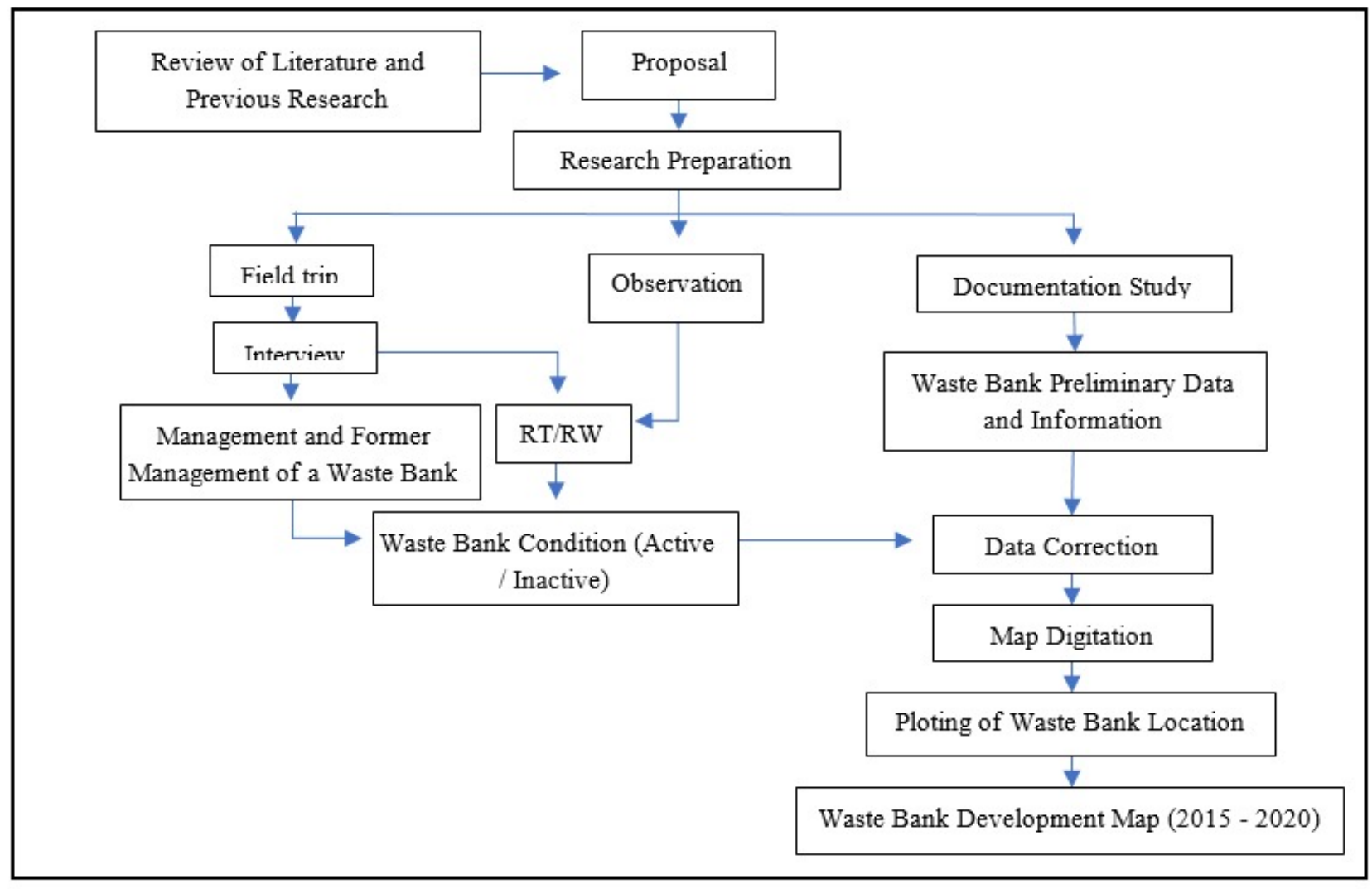

Figure 1. Research Procedure 


\section{FINDINGS AND DISCUSSION}

\subsection{Development of Location and Distribution of Waste Bank}

The results of this study present a data distribution Waste Bank from 2015 to 2020. In the year 2015 recorded Waste Bank in two sub districts only found in five locations, namely Bank Trash available at that time is Melati 08, Cijeruk, Mawarsari 15 Flamboyan 15, and OB MT. Generally located in a fairly dense residential location, this is in line with the high population density, and the activities that occur therein also become a source of the waste contributor (Saputro, et al., 2015). Some are located not far from the Citarum river such as BBA Cijeruk, Flamboyan 15, and OB MT. In Dayeuhkolot District, there is only one Waste Bank, namely OB MT, the rest are in Bojongsoang District (Figure 2).

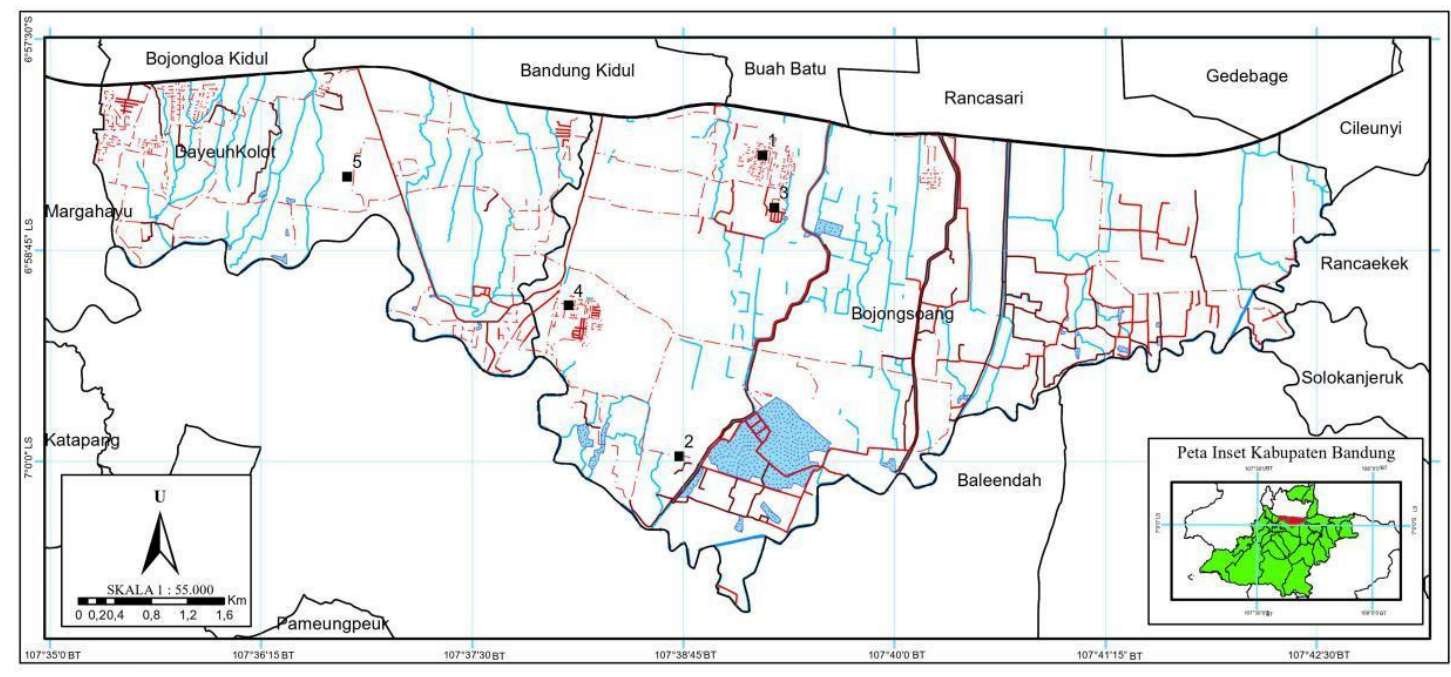

\begin{tabular}{|c|c|c|}
\hline $\begin{array}{c}\text { PETA SEBARAN BANK SAMPAH TAHUN } 2015 \\
\text { KECAMATAN BOJONG SOANG } \\
\text { DAN KECAMATAN DAYEUHKOLOT }\end{array}$ & $\begin{array}{l}\text { Legenda } \\
\begin{array}{|l}\square \text { Batas Administrasi Daerah Kajian }\end{array}\end{array}$ & $\begin{array}{l}\text { Bank Sampah } \\
1 \text { Melati } 08\end{array}$ \\
\hline $\begin{array}{l}\text { DEPARTEMEN PENDIDIKAN GEOGRAFI } \\
\text { FAKULTAS PENDIDIKAN IMUU PENGETAHUAN SOSIAL } \\
\text { UNIVERSITAS PENDIDIKAN INDONESIA }\end{array}$ & $\begin{array}{ll}\text { - } & \text { Bank Sampah } \\
& \text { Sungai } \\
& \text { Jalan Kolektor } \\
- & \text { Jalan Lokal } \\
\text { J Jalan Setapak } & \end{array}$ & $\begin{array}{l}3 \text { Mawarsari } 15 \\
4 \text { Flamboyan } 15 \\
5 \text { OB MT }\end{array}$ \\
\hline 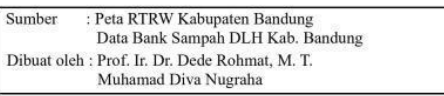 & Danau & \\
\hline
\end{tabular}

Figure 2. Distribution of Waste Bank Location in 2015 in Bojongsoang and Dayeuhkolot Districts

In 2016 the number of Waste Banks increased by five locations, namely Alwahab, Mawarsari, Sauyunan, SMP Telkom, and Citeureup Cempaka. The location is more spread out than the previous year. In Bojongsoang District there are 5 Waste Banks, namely Melati 08, Cijeruk, Mawarsari 15, Flamboyan 15 and Alwahab. In Dayeuhkolot District, there are Waste Bank OB MT, Mawarsari, Sauyunan, SMP Telkom, Citeureup Campaka (Figure 3.) 


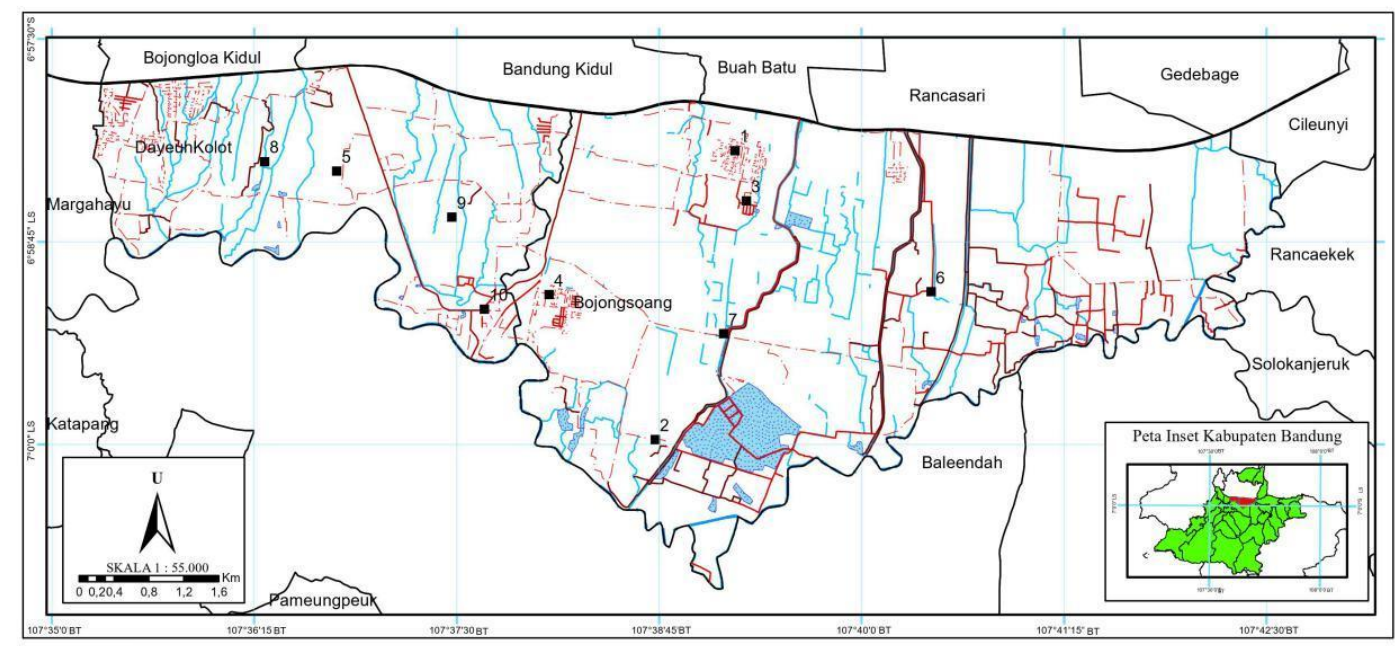

\begin{tabular}{|c|c|c|c|}
\hline $\begin{array}{l}\text { PETA SEBARAN BANK SAMPAH TAHUN } 2016 \\
\text { KECAMATAN BOJONG SOANG } \\
\text { DAN KECAMATAN DAYEUHKOLOT }\end{array}$ & $\begin{array}{l}\text { Legenda } \\
\square \text { Batas Administrasi Daerah Kajian }\end{array}$ & $\begin{array}{l}\text { Bank Sampah } \\
1 \text { Melati } 08\end{array}$ & 6 Alwahab \\
\hline $\begin{array}{l}\text { DEPARTEMEN PENDIDIKAN GEOGRAFI } \\
\text { FAKULAS PENDIIKAN ILNU PENGETAHAN SOSIAL } \\
\text { UNIVERSTTAS PENDIIIKAN INDONESA }\end{array}$ & $\begin{array}{ll} & \text { Batas Administrasi Kecamatan } \\
\text { - } & \text { Bank Sampah } \\
\text { Sungai } \\
\text { Jalan Kolektor } \\
- & \text { Jalan Lokal } \\
\text { Jalan Setapak } & \end{array}$ & $\begin{array}{l}2 \text { BBA Cijeruk } \\
3 \text { Mawarsari } 15 \\
4 \text { Flamboyan } 15 \\
5 \text { OB MT }\end{array}$ & $\begin{array}{l}7 \text { Mawarsari } \\
8 \text { Sauyunan } \\
9 \text { SMP Telkom } \\
10 \text { Clteureup Cempaka }\end{array}$ \\
\hline 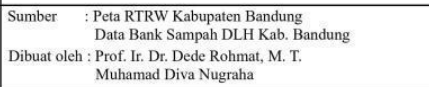 & Danau & & \\
\hline
\end{tabular}

Figure 3. Distribution of Waste Bank Locations in 2016 in Bojongsoang and Dayeuhkolot Districts

In 2017, the addition of Waste Bank significantly from the 10 Waste Bank in 2016 to 28 Waste Bank in 2017. The addition of these particular commons in Sub Bojongsoang. In 2016, in the District of Bojongsoang there Waste Bank by 6 Waste
Bank, while in 2017 to 14 Bank Trash. This means an addition of 8 Waste Banks or 75 percent. In Dayeuhkolot District in 2016, there were 4 Waste Banks and in 2017 there were 8 Waste Banks, or an increase of 50 percent (Figure 4).

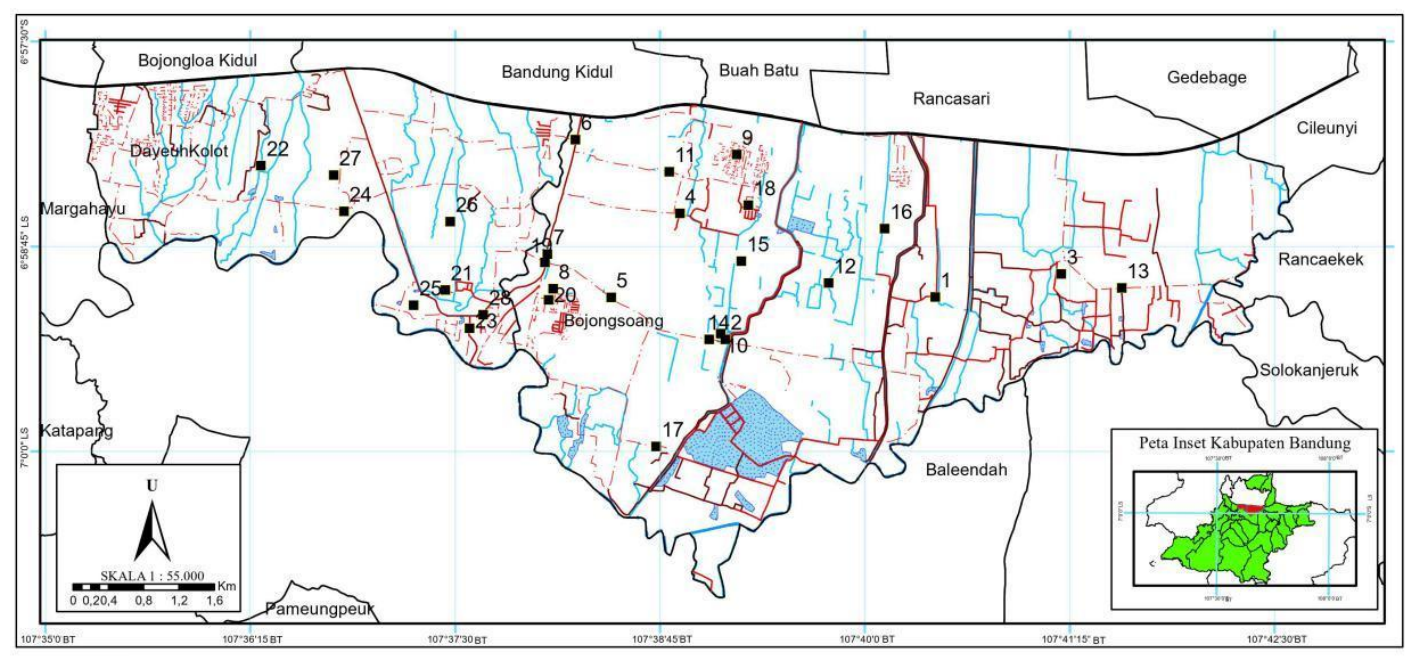

\begin{tabular}{|c|c|c|c|c|}
\hline \multirow{3}{*}{$\begin{array}{c}\text { PETA SEBARAN BANK SAMPAH TAHUN } 2017 \\
\text { KECAMATAN BOJONG SOANG } \\
\text { DAN KECAMATAN DAYEUHKOLOT }\end{array}$} & \multirow{9}{*}{$\begin{array}{l}\text { Legenda } \\
\begin{array}{|l}\text { Batas Administrasi Daerah Kajian } \\
\square \text { Batas Administrasi Kecamatan } \\
\text { Bank Sampah } \\
\text { Sungai } \\
\text { Jalan Kolektor } \\
\text { Jalan Lokal } \\
\text { Jalan Setapak } \\
\text { Danau }\end{array}\end{array}$} & \multicolumn{3}{|l|}{ Bank Sampah } \\
\hline & & 1 Alwahab & 10 Permata RT 3 GPA & 19 Smart Village Lingkungan \\
\hline & & $\begin{array}{l}2 \text { Mawarsari } \\
3 \text { Mawarsari } 04\end{array}$ & 11 YS Grup & 20 Flamboyan 15 \\
\hline & & 4 Citra Lestari 10 & $\begin{array}{l}12 \text { RW } 10 \\
13 \text { Rima Mandiri }\end{array}$ & $\begin{array}{l}21 \text { Bersinar Cempaka Citeureup } \\
22 \text { Sauyunan }\end{array}$ \\
\hline DEPARTEMEN PENDIIIKAN GEOGRAFI & & 5 Mawarsari 12 & 14 Dadang Grup & 23 Flamboyan RW 07 \\
\hline $\begin{array}{l}\text { FAKULTAS PENDIDIKAN ILMU PENGETAHUAN SOSIAL } \\
\text { UNIVERSTITAS PENDIDIKAN INDONESIA }\end{array}$ & & 6 Melat 06 & 15 Mekar Arum 3 & 24 Family \\
\hline :Peta RTRW Kabupaten Bandung & & 7 Mawarsari 03 & 16 Mardiah Balidang & 25 Anggrek 2 \\
\hline Data Bank Sampah DLH Kab. Bandung & & 8 Mawarsari 16 & 17 BBA Cijeruk & 26 SMP Telkom \\
\hline $\begin{array}{l}\text { Dibuat oleh : Prof. Ir. Dr. Dede Rohmat, M. T. } \\
\text { Muhamad Diva Nugraha }\end{array}$ & & 9 Melati 08 & 18 Mawarsari 15 & $\begin{array}{l}27 \text { OB MT } \\
28 \text { Citeurep Cempaka }\end{array}$ \\
\hline
\end{tabular}

Figure 4. Distribution of Waste Bank Location in 2017 in Bojongsoang and Dayeuhkolot Districts 
In 2018, the number of Waste Banks did not increase or equal to 2017, namely 28 locations. The location also remains the same, meaning that there is no change or replacement of the Waste Bank. In 2018, the number of Waste Banks reached its highest level in the two sub-districts. In the following year, some of the Waste Bank was no longer active (Figure 5.).

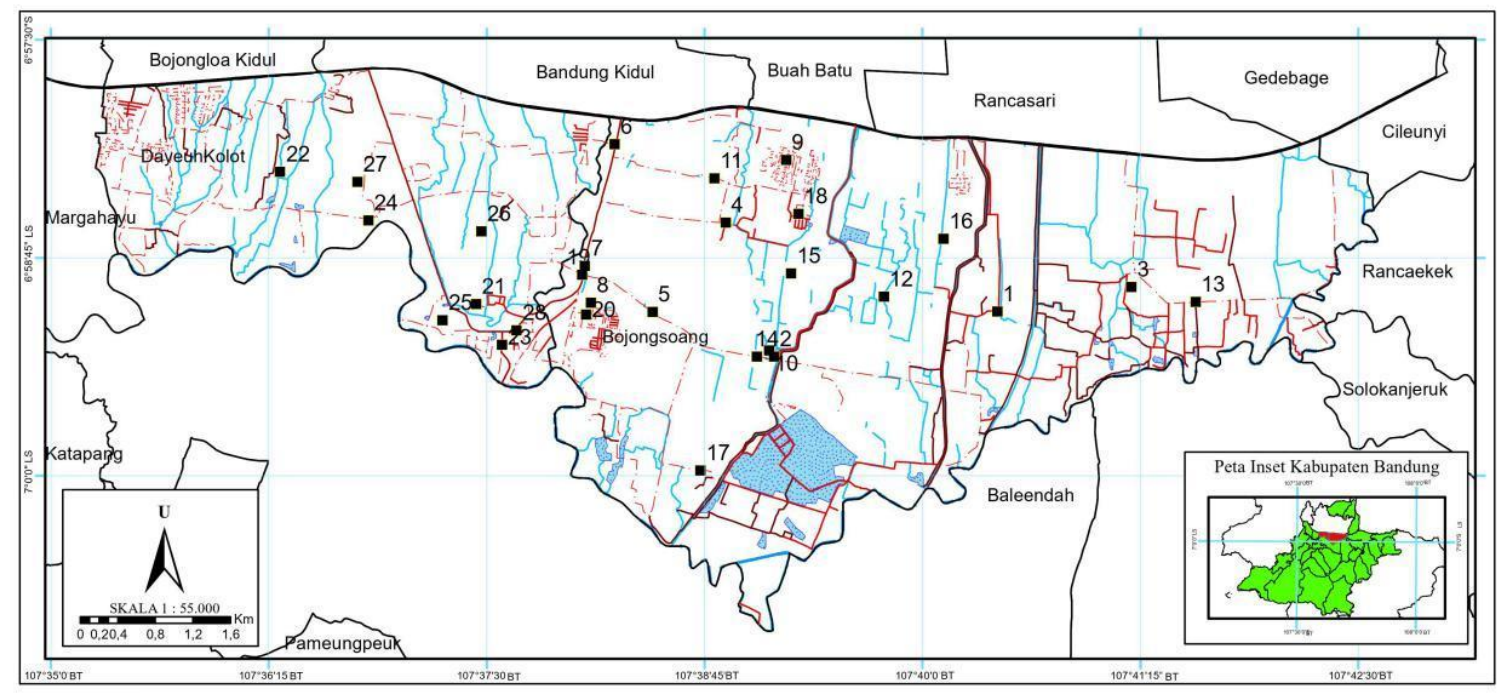

\begin{tabular}{|c|c|c|c|c|}
\hline PETA SEBARAN BANK SAMPAH TAHUN 2018 & \multirow{9}{*}{$\begin{array}{l}\text { Legenda } \\
\begin{array}{|l|l} & \text { Batas Administrasi Daerah Kajian } \\
\square & \text { Batas Administrasi Kecamatan } \\
\text { - } & \text { Bank Sampah } \\
& \text { Sungai } \\
& \text { Jalan Kolektor } \\
- & \text { Jalan Lokal } \\
\text { Jalan Setapak } \\
\text { Danau }\end{array} \\
\end{array}$} & \multicolumn{3}{|l|}{ Bank Sampah } \\
\hline $\begin{array}{l}\text { KECAMATAN BOJONG SOANG } \\
\text { DAN KECAMATAN DAYEUHKOLOT }\end{array}$ & & 1 Alwahab & 10 Permata RT 3 GPA & 19 Smart Village Lingkungan \\
\hline \multirow{4}{*}{$\begin{array}{l}\text { DEPARTEMEN PENDIDIKAN GEOGRAFI } \\
\text { FAKULTAS PENDIIIKAN IMUU PENGETAHUAN SOSIAL } \\
\text { UNIVERSTTAS PENDIDIKAN INDONESIA }\end{array}$} & & $\begin{array}{l}2 \text { Mawarsari } \\
3 \text { Mawarsari } 04\end{array}$ & $\begin{array}{l}11 \text { YS Grup } \\
12 \text { RW } 10\end{array}$ & $\begin{array}{l}20 \text { Flamboyan } 15 \\
21 \text { Bersinar Cempaka Citeureup }\end{array}$ \\
\hline & & 4 Citra Lestari 10 & $\begin{array}{l}12 \text { RW } 10 \\
13 \text { Rima Mandiri }\end{array}$ & $\begin{array}{l}21 \text { Bersinar Cempaka Citeureup } \\
22 \text { Sauyunan }\end{array}$ \\
\hline & & 5 Mawarsari 12 & 14 Dadang Grup & 23 Flamboyan RW 07 \\
\hline & & 6 Melati 06 & 15 Mekar Arum 3 & 24 Family \\
\hline $\begin{array}{ll}\text { Sumber } & \text { : Peta RTRW Kabupaten Bandung }\end{array}$ & & 7 Mawarsari 03 & 16 Mardiah Balidang & 25 Anggrek 2 \\
\hline Data Bank Sampah DLH Kab. Bandung & & 8 Mawarsari 16 & 17 BBA Cijeruk & 26 SMP Telkom \\
\hline $\begin{array}{l}\text { Dibuat oleh : Prof. Ir. Dr. Dede Rohmat, M. T. } \\
\text { Muhamad Diva Nugraha }\end{array}$ & & 9 Melati 08 & 18 Mawarsari 15 & $\begin{array}{l}27 \text { OB MT } \\
28 \text { Citeurep Cempaka }\end{array}$ \\
\hline
\end{tabular}

Figure 5. Distribution of Waste Bank Locations in 2018 in Bojongsoang and Dayeuhkolot District

In 2019, the number of active Waste Banks began to decrease. The map shows the location or distribution of a Waste Bank that is no longer active. From 28 Waste Bank locations in 2018 to only 11 Waste Bank locations, a reduction of 61 percent. In Dayeuhkolot Subdistrict, 3 Waste Bank locations are still active from 8 locations the previous year, while in Bojongsoang District 8 locations are still active from 20 locations in the previous year (Figure 5).

In 2020 a decline in the number of Trash Banks is significant. In that year, almost all Waste Banks were in an inactive condition. There is only one active Waste Bank left, namely the Flamboyan Waste Bank RW 07. The number of Waste Banks that are not active is due to various reasons, namely decreasing community participation, the unstable selling price of waste, change of managers, limited storage places, facilities, and infrastructure. inadequate and lack of government support. In another study (Saputro, 2017) it is said that the decline in participation in utilizing the Waste Bank is because people tend to sell to scavengers or collectors. After all, the price offered is higher than the price offered by the Waste Bank. The condition is getting worse with the emergence of pandemic covid-19 so that the unit Waste Bank can not survive because there are no people who are depositing garbage (Figure 6). 


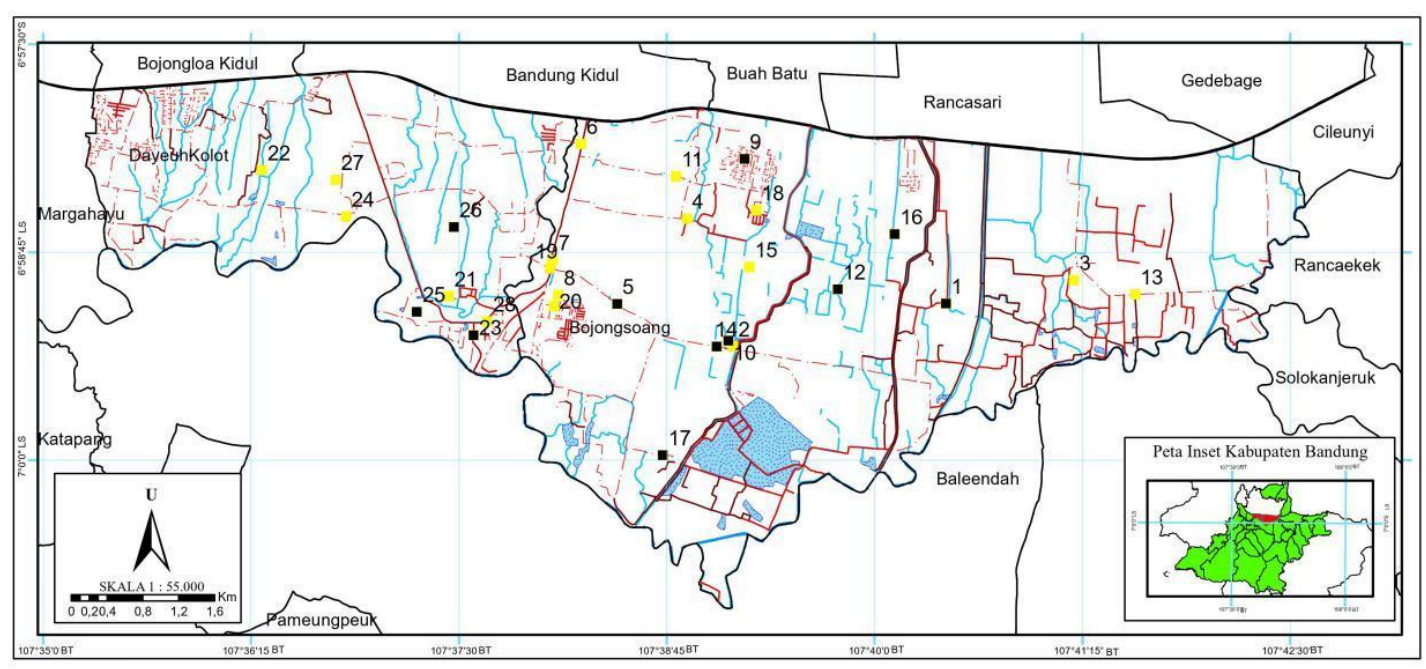

\begin{tabular}{|c|c|c|c|c|}
\hline $\begin{array}{l}\text { PETA SEBARAN BANK SAMPAH TAHUN } 2019 \\
\text { KECAMATAN BOJONG SOANG } \\
\text { DAN KECAMATAN DAYEUHKOLOT }\end{array}$ & $\begin{array}{l}\text { Legenda } \\
\square \text { Batas Administrasi Daerah Kajian }\end{array}$ & $\begin{array}{l}\text { Bank Sampah } \\
1 \text { Alwahab } \\
2 \text { Mawarsari }\end{array}$ & $\begin{array}{l}10 \text { Permata RT } 3 \text { GPA } \\
11 \text { YS Grup }\end{array}$ & $\begin{array}{l}19 \text { Smart Village Lingkungan } \\
20 \text { Flamboyan } 15\end{array}$ \\
\hline $\begin{array}{l}\text { DEPARTEMEN PENDIDIKAN GEOGRAFI } \\
\text { FAKULTAS PENDIIKAN IMUU PEGETAHUAN SOSIAL } \\
\text { UNIVERSTTAS PENDIDIKAN INDONESIA }\end{array}$ & $\begin{array}{l}\text { - Bank Sampah Aktif } \\
\text { Bank Sampah Non Aktif } \\
\text { - Sungai } \\
\text { - Jalan Kolektor } \\
\text { _- Jalan Lokal }\end{array}$ & $\begin{array}{l}3 \text { Mawarsari } 04 \\
4 \text { Citra Lestari } 10 \\
5 \text { Mawarsari } 12 \\
6 \text { Melati } 06 \\
7 \text { Mawarsari } 03\end{array}$ & $\begin{array}{l}12 \text { RW } 10 \\
13 \text { Rima Mandiri } \\
14 \text { Dadang Grup } \\
15 \text { Mekar Arum } 3\end{array}$ & $\begin{array}{l}21 \text { Bersinar Cempaka Citeureup } \\
22 \text { Sauyunan } \\
23 \text { Flamboyan RW } 07 \\
24 \text { Family } \\
25 \text { Angorek } 2\end{array}$ \\
\hline $\begin{array}{l}\text { Sumber } \quad \text { : Peta RTRW Kabupaten Bandung } \\
\text { Data Bank Sampah DLH Kab. Bandung } \\
\text { Dibuat oleh : Prof. Ir. Dr. Dede Rohmat, M. T. } \\
\text { Muhamad Diva Nugraha } \\
\text { Mula }\end{array}$ & 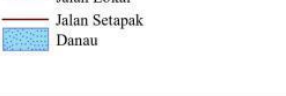 & $\begin{array}{l}7 \text { Mawarsari } 03 \\
8 \text { Mawarsari } 16 \\
9 \text { Melati } 08\end{array}$ & $\begin{array}{l}16 \text { Mardiah Balidang } \\
17 \text { BBA Cijeruk } \\
18 \text { Mawarsari } 15\end{array}$ & $\begin{array}{l}25 \text { Anggrek } 2 \\
26 \text { SMP Telkom } \\
27 \text { OB MT } \\
28 \text { Citeurep Cempaka }\end{array}$ \\
\hline
\end{tabular}

Figure 6. Distribution of Waste Bank Locations in 2019 in Bojongsoang and Dayeuhkolot Districts

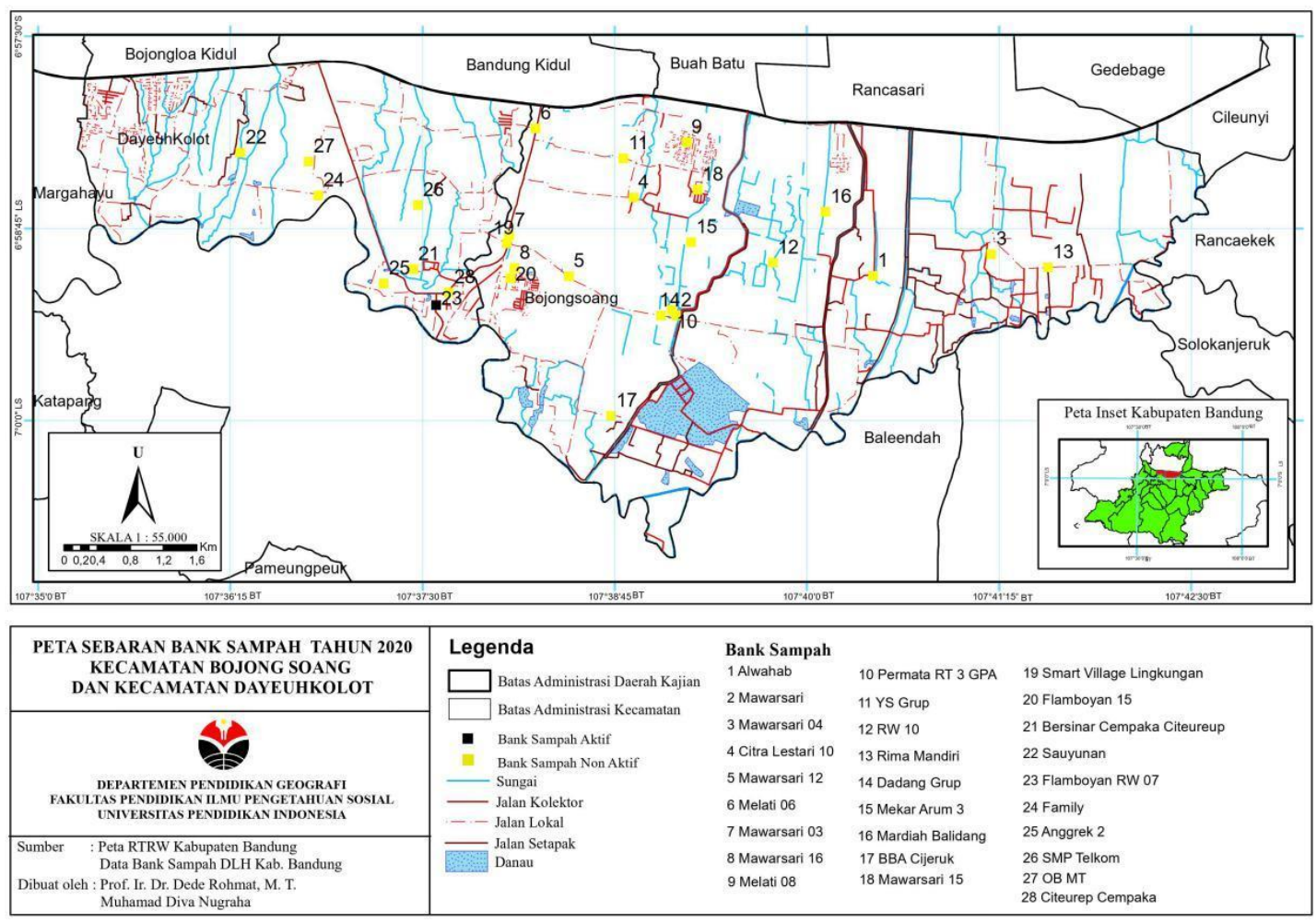

Figure 7. Distribution of Waste Bank Location in 2020 in Bojongsoang and Dayeuhkolot District 


\section{CONCLUSIONS}

The Waste Bank Program shows an increasing trend since the beginning of its development in 2015 and reaching its peak in 2017. However, there is a tendency to decrease in number. In fact, in 2020 only one location is still operating. Even though it is conceptually ideal, in its implementation there are quite a lot of challenges/obstacles. Some of these obstacles are decreased community participation, the unstable selling price of waste, change of managers, limited shelter, inadequate facilities, and infrastructure and lack of government support.

\section{RECOMMENDATIONS}

The Waste Bank Program is a very good program to support the Citarum Harum program. However, there is a need for community empowerment in terms of knowledge and insight as well as concern for environmental problems. Therefore, assistance or guidance by the government should be intensive. The Waste Bank Management together with the government also needs to make efforts so that the economic value of waste increases so that the community's participation will also increase.

\section{REFERENCES}

Badan Pusat Statistik, 2018.

Cahyaningsih, A., \& Harsoyo, B. 2010. Distribusi spasial tingkat pencemaran air di DAS Citarum. Jurnal Sains \& Teknologi Modifikasi Cuaca,11(2),1-9.

Dwiyanto. BM, 2011. Model Peningkatan Partisipasi Masyarakat dan Penguatan Sinergi dalam Pengelolaan

Sampah Perkotaan, 239-256.
Direktorat Pengembangan Penyehatan Lingkungan Permukiman Ditjen Cipta Karya Kementerian Pekerjaan Umum, 2011, Materi Bidang Sampah I Diseminasi dan Sosialisasi Keteknikan Bidang P L $P$, Direktorat Pengembangan Penyehatan Lingkungan Permukiman Ditjen Cipta Karya Kementerian Pekerjaan Umum, Jakarta

Dyah Marganingrum, Dwina Roosmin, Pradono, dan Arwin Sabar 2013. Diferensiasi Sumber Pencemar Sungai Menggunakan Pendekatan Metode Indeks Pencemar (IP) (Studi Kasus : Hulu DAS Citarum)

Ermawati, R., \& Hartono, L. 2017. Pemetaan Sumber Pencemaran Sungai Lamat Kabupaten Magelang. Jurnal Sains \& Teknologi Lingkungan, 9 (2), 92-104.

Fardiaz S (1992) Polusi Air dan Udara. Penerbit Kanisius. Jakarta

Friedberg, E., Hilderbrand, M.E. 2017, Observing Policy-Making in Indonesia. Singapore: Springer Nature Singapore Pte Ltd.

Hartono, H., Widiasih, S., \& Ismowati, M. 2020. Analisis Inovasi Bank Sampah Dalam Pengelolaan Sampah Rumah Tangga Perkotaan Di Kelurahan Bahagia Kecamatan Babelan Kabupaten Bekasi. Jurnal Reformasi Administrasi: Jurnal Ilmiah untuk Mewujudkan Masyarakat Madani, 7(1), 41-49.

Pamungkas, R. W. P., \& Khalida, R. 2019. Monitoring Sebaran Petugas Lapangan Citarum Harum dalam Pelaporan

Digital. SISFOTENIKA, 9(1), 71-81.

Pariatamby, A., Tanaka, M. 2014, Municipal Solid Waste 
Management in Asia and the Pasific Island: Challenges and Strategic Solutions. Singapore: SpringerVerlag.

Peraturan Menteri Lingkungan Hidup Republik Indonesia Nomor 13 Tahun 2012 Tentang Tentang Pedoman Pelaksanaan Reduce ,Reuse dan Recycle melalui Bank Sampah

Rohmat, Dede, Iwan Setiawan dan Asri Afriani 2018. Zonasi Karakteristik Pencemaran Untuk Penyusunan Strategi Dan Pola Aksi Penanganan Sungai Menuju Citarum Harum (Pemetaan Dengan Citra Tegak Resolusi Tinggi)

Yayasan Unilever Indonesia, 2013. Buku Panduan Sistem Bank Sampah \& 10 Kisah Sukses, Yayasan Unilever Indonesia, Jakarta.
Rosita, T. 2017. Pemberdayaan Masyarakat Pemulung Melalui Pengelolaan Limbah di Sungai Citarum. Jurnal Ilmiah P2M STKIP Siliwangi, 4(2), 12-19.

Saputro, Y. E., Kismartini, K., \& Syafrudin, S. 2016. Pengelolaan sampah berbasis masyarakat melalui Bank Sampah. Indonesian Journal of Conservation, 4(1).

Surjandari, I., Hidayatno, A., \& Supriatna, A. 2009. Model dinamis pengelolaan sampah untuk mengurangi beban penumpukan. Jurnal Teknik Industri, 11(2), 134-147. 